\title{
Milk production from silage: comparison of grass, legume and maize silages and their mixtures
}

\author{
Richard J. Dewhurst \\ Teagasc, Animal and Grassland Research \& Innovation Centre, Grange, Dunsany, Co. Meath, Ireland \\ e-mail: richard.dewhurst@teagasc.ie
}

\begin{abstract}
The high rates of rumen fermentation, physical breakdown and passage rates from the rumen of legume silages lead to higher intakes than for grass silages of comparable digestibility. Although total tract digestibilities for legume silages and maize silages are often lower than for grass silages, milk yields are usually higher. A further benefit of legumes and maize is the reduced rate of decline in digestibility. Legume silages often lead to a reduction in milk fat concentration and increased levels of polyunsaturated fatty acids, $18: 2 n-6$ and 18:3n-3. This latter effect is related to reduced rumen biohydrogenation as a consequence of increased rumen passage rates or the effects of polyphenol oxidase. There is quite a wide range of maturities $\left(300-350 \mathrm{~g} \mathrm{~kg}^{-1} \mathrm{DM}\right)$ that leads to maximum dry matter intakes and milk production from maize silage; milk production is reduced with immature or over-mature maize crops. Forage chop length exerts a number of effects, both in the silo and in the rumen, but effects on rumen function, feed intake and milk production have been inconsistent. The high protein content and high $\mathrm{N}$ degradability of most legume silages is associated with a low efficiency of converting dietary $\mathrm{N}$ into milk $\mathrm{N}$, with a concomitant increase in urine $\mathrm{N}$. Reducing $\mathrm{N}$ intake by inclusion of maize silage in mixtures with legume silages leads to a marked reduction in urine $\mathrm{N}$ without loss of production potential. It is predicted, on the basis of their chemical composition and rumen kinetics, that legume silages and maize silages would reduce methane production relative to grass silage, though in vivo measurements are lacking. Extensive fermentation in the silo reduces the amount of fermentable substrate, and reduced methane production in comparison with grass silage where fermentation had been restricted by high levels of acid additive.
\end{abstract}

Key words: clover silage, feed intake, grass silage, maize silage, milk quality

\section{Introduction}

This paper focuses on silages used for milk production in the maritime region of North-West Europe. Following the transition from hay to silage over the last half century, the main forage on many dairy farms is often grass silage, typically based on timothy (Phleum pratense) and meadow fescue (Festuca pratensis) in cooler areas, and ryegrasses (Lolium spp.) in more temperate areas. There are areas where red clover (Trifolium pratense) and maize (Zea mays) are important, and experience in these areas has prompted renewed interest in alternative forages in other areas. Maize is a tropical crop and so has not always achieved an adequate level of maturity in cooler parts of the region; the use of other whole-crop cereals has expanded in some of these areas. Plant breeders have made considerable advances in achieving earlier maturing maize varieties that are more reliable in areas such as Northern Britain and Ireland.

The main focus of the paper is on feed intake, milk production and milk composition when cows are offered diets based on silages prepared from grass, red clover, white clover (Trifolium repens) or maize. The high production potential of legume silages has long been recognised - both for white clover (Castle et al. 1983), red clover (Thomas et al. 1985), and lucerne (Medicago sativa; Hoffman et al. 1998). Some early studies evaluated milk production potential with silage as sole feed. Castle (1982) obtained milk yields of between 13.3 and $16.0 \mathrm{~kg}^{\text {day }}{ }^{-1}$ from high-digestibility grass silage as sole feed in mid-lactation. Rae et al. (1987) conducted a multi-year study with spring-calving cows offered just grass silage and grazed grass. At one location, with high-quality silage, they obtained lactation yields of $4700 \mathrm{~kg}$ without feeding concentrates. Mean silage dry matter (DM) intakes were 13.2 $\mathrm{kg}$ day $^{-1}$ and mean milk yields were $21.1 \mathrm{~kg} \mathrm{day}^{-1}$ for cows and $16.1 \mathrm{~kg} \mathrm{day}^{-1}$ for heifers in the 3-month period prior to turnout. Particularly impressive were the DM intakes (19.3 and $17.7 \mathrm{~kg} \mathrm{day}^{-1}$ ) and milk yields (26.8 and $19.6 \mathrm{~kg}$ day $^{-1}$ ) achieved by Castle et al. (1984) and Cohen et al. (2006) respectively with white clover silage as sole feed. Steinshamn and Thuen (2008) recorded milk yields of $22 \mathrm{~kg}$ day ${ }^{-1}$ when they offered diets based on grass silage with either white clover silage ( 0.28 of DM) or red clover silage ( 0.42 of DM) as sole-feed to cows in early lactation (average 74 days in milk). In addition to considering the effects of different silages on productivity and milk composition, this paper also considers effects on nutrient efficiency and emissions. 


\section{Chemical composition and digestibility}

Table 1 uses mean feed values taken from INRA (2007) to illustrate the mean and range for grass, legume and maize silages. These relate to conditions in France, but the pattern of greater variation in grasses in comparison with legumes is evident in other areas (Dewhurst et al. 2003b, Hetta et al. 2004).

Table 1. Range of composition of different silages in feed tables from France (INRA 2007).

\begin{tabular}{|c|c|c|c|}
\hline & & $\begin{array}{c}\text { Unité Fourragère Lait } \\
\text { (per kg DM) }\end{array}$ & $\begin{array}{c}\text { Crude protein } \\
\left(\mathrm{g} \mathrm{kg}^{-1} \mathrm{DM}\right)\end{array}$ \\
\hline \multirow[t]{5}{*}{ Perennial ryegrass } & $1^{\text {st }}$ cut, prior to $10 \%$ ear emergence & 1.01 & 151 \\
\hline & $1^{\text {st }}$ cut, $10 \%$ ear emergence & 0.97 & 141 \\
\hline & $1^{\text {st }}$ cut, end of heading & 0.83 & 112 \\
\hline & $2^{\text {nd }}$ cut, stemmy, heading & 0.83 & 131 \\
\hline & Range (\% of highest value) & 17.8 & 13.2 \\
\hline \multirow[t]{4}{*}{ Lucerne } & 1 st cut, $10 \%$ budding & 0.82 & 190 \\
\hline & $1^{\text {st }}$ cut, $50 \%$ budding & 0.77 & 182 \\
\hline & $2^{\text {nd }}$ cut, stemmy, budding & 0.76 & 187 \\
\hline & Range (\% of highest value) & 7.3 & 4.2 \\
\hline \multirow[t]{4}{*}{ Red clover } & 1 st cut, $10 \%$ budding & 0.90 & 178 \\
\hline & $1^{\text {st }}$ cut, $50 \%$ budding & 0.86 & 171 \\
\hline & $2^{\text {nd }}$ cut, stemmy, budding & 0.81 & 181 \\
\hline & Range (\% of highest value) & 10.0 & 5.5 \\
\hline \multirow[t]{4}{*}{ Maize } & Milk-dough (250 gDM kg-1) & 0.90 & 86 \\
\hline & Dough-flint (300 gDM kg-1) & 0.90 & 84 \\
\hline & Flint $\left(350 \mathrm{gDM} \mathrm{kg}^{-1}\right)$ & 0.90 & 82 \\
\hline & Range (\% of highest value) & 0 & 4.6 \\
\hline
\end{tabular}

'Unité Fourragère Lait (UFL) is a Net Energy for Lactation Unit in the French Feeding System and is expressed relative to barley, which has a value of 1 UFL.

Legumes generally contain more protein and less fibre than grasses, whilst maize contains less protein and less fibre than grass. Early work suggested that the rate of decline in digestibility is less for legumes than grasses (Ulyatt 1970, Thomas et al. 1981). Rinne and Nykänen (2000) showed a more rapid decline in the digestibility of timothy than red clover during primary growth. Hetta et al. (2004) showed that the rate of decline in digestibility was greater for timothy than for red clover during spring growth, but not during summer growth. Phipps et al. (2000) evaluated maize silages of widely divergent maturity, varying from 230 to $380 \mathrm{gDM} \mathrm{kg}^{-1}$. Starch replaced fibre as the crop matured from 230 to $330 \mathrm{gDM} \mathrm{kg}^{-1}$ (NDF: $570 \mathrm{vs.} 430 \mathrm{~g} \mathrm{~kg}^{-1} \mathrm{DM}$; starch: $110 \mathrm{vs.} 310 \mathrm{~g} \mathrm{~kg}^{-1} \mathrm{DM}$ ).

Digestibility of silages is affected both by rates of fermentation in the rumen, and residence time within the digestive tract. The higher rates of fermentation for legumes in comparison with grasses (Smith et al. 1972), as well as higher rates of physical breakdown and passage from the rumen (Wilson and Kennedy 1996) have long been recognised. The higher rates of fermentation of clover silages have been confirmed in more recent work (Dewhurst et al. 2003a). White clover has relatively low fibre content and an inherently high rate of fermentation, so that despite a much lower retention time than ryegrass (and consequent higher intake), it remains more digestible than ryegrass (Dewhurst et al. 2003a). 


\section{Rumen function}

Despite the differences in rumen fermentation rates, Dewhurst et al. (2003a) found no effect of legume silages (white clover, red clover or lucerne) on rumen pH or VFA concentrations, though rumen ammonia-N concentrations were significantly higher than for diets based on grass silage. Whilst Vanhatalo et al. (2009) confirmed the increased rumen ammonia- $\mathrm{N}$ when feeding red clover silage (in comparison with grass silage), they also observed higher VFA concentrations and a higher molar proportion of acetic acid.

Whilst legumes may be attractive diet components for other reasons, their high crude protein content can lead to wastage of nitrogen, so there has been interest in reducing the rumen degradation of $\mathrm{N}$. Table 2 summarises some data from nylon bag studies of $\mathrm{N}$ degradation with grasses and legumes at different growth stages. Overall, estimates for legumes were higher than for perennial ryegrass, though Hoffman et al. (1993) found higher values for perennial ryegrass when comparisons were made with immature herbage. The values in Table 2 were calculated using an estimated rumen outflow rate of 0.05 per hour, though as has been noted this may be higher for the legumes, which would reduce the differences.

Table 2. Estimates of nitrogen degradability $\left(\mathrm{g} \mathrm{g}^{-1}\right)$ of forage legumes, assuming a rumen outflow rate of 0.05 hour-1.

\begin{tabular}{|c|c|c|c|c|}
\hline & Perennial ryegrass & White clover & Red clover & Lucerne \\
\hline Fresh herbage: early season ${ }^{1}$ & 0.70 & 0.83 & & \\
\hline Fresh herbage: mid season ${ }^{1}$ & 0.67 & 0.79 & & \\
\hline Fresh herbage: late season ${ }^{1}$ & 0.67 & 0.75 & 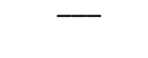 & \\
\hline Dried herbage: vegetative ${ }^{2}$ & 0.89 & & 0.88 & 0.85 \\
\hline Dried herbage: bud/boot ${ }^{2}$ & 0.87 & - & 0.82 & 0.79 \\
\hline Dried herbage: flowering ${ }^{2}$ & 0.69 & - & 0.73 & 0.73 \\
\hline Dried silage: mixed cuts ${ }^{3}$ & 0.76 & 0.83 & 0.77 & - \\
\hline
\end{tabular}

${ }^{1}$ Beever et al. 1986, ${ }^{2}$ Hoffman et al. 1993, ${ }^{3}$ Dewhurst et al. 2003a

Dewhurst et al. (2003a) showed similar soluble ('a') and insoluble but potentially degradable ('b') fractions for $\mathrm{N}$ in grass silage and white clover silage, but a much higher degradation rate for white clover silage (0.063 vs. 0.031 hour $\left.{ }^{-1}\right)$. For red clover silage, the 'a' fraction was reduced (' $b$ ' fraction increased) and the degradation rate intermediate $\left(0.046\right.$ hour $\left.^{-1}\right)$. Broderick et al. (2004) evaluated a wide range of accessions of red clover and lucerne, using an in vitro system, in order to obtain a comprehensive description of the range of $\mathrm{N}$ degradability for these forages. They confirmed that $\mathrm{N}$ degradability was lower for red clover than for lucerne. This appears to be related to the action of PPO in producing protein-quinone complexes that are resistant to rumen degradation (Lee et al. 2008). Condensed tannins present in other forage legumes, such as sainfoin, remain activ in silages and have altered the partitioning of dietary $\mathrm{N}$ between urine and faeces in sheep (Theodoridou et al. 2012). However, these crops are not agronomically suited to typical silage production systems for dairy cows in North-West Europe and red clover remains the most promising crop with reduced rumen $\mathrm{N}$ degradability. Recent work has demonstrated PPO activity in cocksfoot (Lee et al. 2006) and plant breeders are now considering ways to introduce this beneficial activity into grasses that are used more frequently for silage production (Kingston-Smith et al. 2013).

Results based on urinary excretion of purine derivatives provide little evidence for the effects of different silages on N-use efficiency (NUE) being mediated via effects on microbial protein synthesis. The low NUE with diets based on legume silages, particularly lucerne silage (Dewhurst et al. 2003b), were associated with increased microbial efficiency (g microbial N per kg digested organic matter; Dewhurst et al. 2003a). Further, there were no consistent effects of microbial efficiency associated with increased NUE for legume/cereal silage mixtures (Dewhurst et al. 2010, Cheng et al. 2011).

\section{Rumen methanogenesis}

High-forage diets have long been known to lead to production of more methane per unit of energy intake than high-concentrate diets (Blaxter and Clapperton 1965) and this is a particular challenge to production systems based on high levels of forage, including silage. The high fibre, high rumen $\mathrm{pH}$ and low rumen passage rates all favour rumen methanogenic archaea (Beauchemin et al. 2008). 
There are a number of reasons to predict that methane production should be less from legumes than from grass, including lower fibre content, higher DM intakes and an increased passage rate from the rumen (Beauchemin et al. 2008). A number of early studies with fresh herbage showed reduced methane from legumes (McCaughey et al. 1999, Waghorn et al. 2006). We have used a methanogen marker (archaeol) to show a reduced archaeal population after a meal of white clover (McCartney et al. 2012), presumably reflecting the difficulty that archaea have in surviving when intake and rumen passage rates are high. However, evidence from feeding studies with silages does not confirm this effect. Van Dorland et al. (2007) found no difference between grass silage, red clover silage and white clover silage in their effects on methane output, whether expressed per day, per $\mathrm{kg}$ of milk, or per $\mathrm{kg}$ digested organic matter, though clover silages only made up 0.40 of forage mixtures which also contained 0.60 ryegrass silage.

Extensive fermentation in the silo leaves a reduced proportion of dietary energy available for rumen fermentation, so it would be expected that methane production is reduced. Cushnahan et al. (1995) demonstrated this effect with significantly less methane production from extensively-fermented grass silage, prepared with a bacterial inoculant, in comparison with grass silage prepared from the same herbage, with a high rate of application of an acid-based additive. Unfortunately, the overall reduction in methane production was counteracted by an increase in urine $\mathrm{N}$, so there may be no net effect on greenhouse-gas emissions when methane and potential nitrous oxide are taken into account.

Whilst it is envisaged that the higher starch content and lower fibre content of maize silage will lead to reduced methane production in comparison with diets based on grass silage, this has not been verified experimentally (Beauchemin et al. 2008). Further, Vellinga and Hoving (2011) caution that reductions in methane production from feeding maize silage may be offset by the loss of soil carbon associated with ploughing permanent pasture to grow maize.

\section{Feed intake}

The lower intakes of grass silages are the most remarkable feature when comparisons are made across silage types. Legume silages generally lead to higher intakes than grass silages of comparable digestibility. Huhtanen et al. (2007) in a meta analysis showed a curvilinear effect with increasing intakes as legume silages replaced grass silages up to 0.80 inclusion. The same situation applied when Cheng et al. (2011) compared grass silages with mixtures of legume and cereal silages - despite lower digestibilities, the latter led to higher intakes. This effect is not confined to legume silages - total intakes and short-term intakes of total-mixed rations based on maize silage where higher than those based on grass silage (Abrahamse et al. 2008).

Rinne et al. (2002) investigated feed intake and rumen function for a series of timothy/meadow fescue silages of increasing maturity. The increased intakes of early-cut grass silage were associated with a reduction in rumen fill, suggesting that rumen fill is not solely responsible for control of feed intake. The effects of the level and composition of nutrients derived from silages, and their interaction with animal potential, are also important in regulation of silage intake. There have been few studies of the effects of stage of maturity on intake and milk production from red clover silage. Hoffman et al. (1997) showed reductions in intakes of red clover silage in two separate years (milk yields were also reduced in one of the studies), whilst Vanhatalo et al. (2009) showed a significant increase in intake with a more mature red clover silage. Vanhatalo et al. (2008) showed reductions in intake with more mature red clover silages, whether from primary growth or regrowths. They found significantly higher intakes of red clover silages prepared from regrowths as opposed to primary growths.

With the exception of diets that contain less than $250 \mathrm{~g} \mathrm{NDF} \mathrm{kg}^{-1} \mathrm{DM}$ and are likely to be associated with rumen acidosis, there is a general negative relationship between diet NDF and DM intake (Allen et al. 2000). The fibre content of white clover silage is much lower than in other silages (Dewhurst et al. 2003b) and this explains the high intake characteristics, both as sole forage (Castle et al. 1984, Cohen et al. 2006), and with concentrate feeding (Dewhurst et al. 2003b). However, the fibre content of silages from grass, lucerne, red clover and maize are more similar and other mechanisms must explain differences in feed intake. The higher intake of these silages relative to grass silage relates to their more rapid fermentation and physical breakdown within the rumen.

Differences in intake have been attributed to both faster rates of fermentation (Beever and Thorp 1996) and more rapid particle breakdown and clearance from the rumen (Moseley and Jones 1984, Waghorn et al. 1989, Jamot and Grenet 1991). Dewhurst et al. (2003a) suggested that fermentation rate may be more important for white clover 
silage, whilst rapid particle breakdown may be more important for lucerne silage. Bosch and Bruining (1995) compared grass silages at differing maturities and suggested that the control of rumen fill is related to the disappearance rate of small particles $(0.07$ to $1.25 \mathrm{~mm}$ ) from the rumen. In comparison with the elongated vein structure of grasses, the reticular vein structure of legumes breaks down into small particles more readily (Wilman et al. 1996, Wilson and Kennedy 1996). Since fermentation may contribute to the buoyancy of rumen particles, which limits the ability to leave the rumen (Baumont and Deswysen 1991), more rapid fermentation would also increase passage rates from the rumen. Some aspects of intake regulation of legume silages remain to be elucidated; Kuoppala et al. (2009) could not explain the low intakes of early-cut red clover silage in terms of silage digestibility, fermentation quality or rumen fill and concluded that it must be related to some other aspect of nutrient composition.

Intakes of mixtures of grass and legume silages were usually intermediate to intakes of the grass and legume silages separately (Dewhurst et al. 2003b). High intakes were also achieved with mixtures of red clover silage and maize silage (Dewhurst et al. 2010). Intakes of maize silage increase with increasing maturity, up to the optimal 300-350 gDM kg $^{-1}$ (Phipps 1990).

There has been a lot of work, particularly in North America, over the last decade evaluating effects of varying chop length in a range of forages, including lucerne, maize and oat silage. Part of the reason for this interest is the better compaction and ensiling that can be achieved with shorter chop material. At the same time, the short forage particles will increase problems with sub-acute rumen acidosis because of increased fermentation rates and reduced chewing, rumination and saliva production. Whilst a number of studies showed effects on rumen fermentation measures, there were no consistent effects on feed intake, milk production or milk composition (Bhandari et al. 2007, 2008). Working with dairy steers, Rustas et al. (2010) showed an effect of chopping fermented wholecrop barley silage on DM intake when the crop was harvested at the mid-dough stage (Zadoks code 85), but not when it was harvested three weeks earlier at the heading stage (Zadoks code 59).

The basis for differences in DM intake between well preserved grass silages is less clear. Kuoppala et al. (2009, 2010) compared silages prepared from primary growth and regrowth of timothy/meadow fescue at two growth stages. They found no explanation for the higher intake and milk production from first-cut silages, despite extensive studies of feed chemistry, kinetics of rumen digestion and passage, and the protein/energy ratio of absorbed nutrients. The lack of explanation for differences in intake characteristics between silages from different herbage species and managements is an important area for further research because these effects drive the differences in milk production and nutrient utilisation described below. Whilst we understand some of the mechanisms involved in regulating silage intake, and have some analytical tools, new insights are needed. For example, Huhtanen et al. (2007) speculated that microbiology of herbage and the proportion of dead material may explain some of the difference between first-cut and later silages.

\section{Milk production}

Diets based on legume silages, maize silage, or mixtures of the two often lead to higher milk production than diets based on grass silage (e.g. Thomas et al. 1985, Phipps et al. 1988, 1992, R.J. Dewhurst, unpublished observations). However, in most situations diets often involve mixtures of these silages with grass silage. With averagequality grass silage, Phipps et al. (1992) found that a 50/50 mixture of grass silage and maize silage maximised intakes and milk production, whilst with a poorer grass silage, the optimal mixture was 75/25 maize silage/grass silage. Comparisons of milk production from lucerne silage and red clover silage are equivocal (Hoffman et al. 1997, Broderick et al. 2000, 2001, Dewhurst et al. 2003b).

Grasses and legumes tend to contain adequate levels of crude protein, so that production is limited by their intake characteristics and energy content. Red clover and lucerne silage can often be of lower digestibility than grass silage, but performance can be higher as a result of higher DM intakes (lucerne: Hoffman et al. 1998; red clover silage: Dewhurst et al. 2003b, Moorby et al. 2009).

Although legume silages generally lead to higher intakes and milk production than grass silages, there remains considerable variation due to weather conditions and the success of ensilage, so there are examples of legume silages with lower intake and production characteristics (Bertilsson and Murphy 2003).

Milk yields were maximised using maize silage of $330 \mathrm{gDM} \mathrm{kg}^{-1}$ (310 g starch $\left.\mathrm{kg}^{-1} \mathrm{DM}\right)$ in the study of Phipps et al. (2000), which compared a range from 230 to $380 \mathrm{gDM} \mathrm{kg}^{-1}$. There was no further increase in production with 


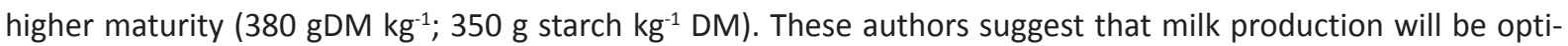
mised across a relatively wide range of maize silage maturity (300-350 $\left.\mathrm{gDM} \mathrm{kg}^{-1}\right)$, though this optimal range may be different for special maize varieties such as 'staygreen' maize.

\section{Milk fat and protein content}

Phipps et al. (1992) found no effect of varying the ratio of grass silage to maize silage from $100 / 0$ to $75 / 25$ in the diet on fat concentration or protein concentration. Similarly, there appears to be little difference between grass silage and lucerne silage in their effects on milk fat concentration and protein concentration. Legume silages have often led to reductions in milk fat concentration and/or milk protein concentration and this is summarised in Table 3. The reduction in milk fat concentration with clover silages is most consistent, with reductions in milk protein concentration often small and occasional significant increases in milk protein concentration when clover silages with exceptionally high intake characteristics were fed.

\begin{tabular}{|c|c|c|c|}
\hline Reference $^{(+)}$ & Comparison & $\begin{array}{l}\text { Effect of clover silage on milk } \\
\text { fat concentration }\end{array}$ & $\begin{array}{l}\text { Effect of clover silage } \\
\text { on milk protein } \\
\text { concentration }\end{array}$ \\
\hline Al-Mabruk et al. 2004 & Red clover vs. grass & No effect & Small increase \\
\hline Bertilsson \& Murphy 2003 (1) & Red clover vs. grass & No effect & No effect \\
\hline Bertilsson \& Murphy 2003 (2) & Red clover vs. grass & No effect & Reduction \\
\hline Dewhurst et al. 2003a (1) & Red clover vs. grass & No effect & No effect \\
\hline Dewhurst et al. 2003a (2) & Red clover vs. grass & No effect & Small reduction \\
\hline Moorby et al. 2009 & Red clover vs. grass & Reduction & Reduction \\
\hline Thomas et al. 1985 & Red clover vs. grass & Reduction & No effect \\
\hline Vanhatalo et al. 2009 & Red clover vs. grass & Reduction & Reduction \\
\hline Bertilsson \& Murphy 2003 (1) & White clover vs. grass & No effect & No effect \\
\hline Bertilsson \& Murphy 2003 (2) & White clover vs. grass & Reduction & Reduction \\
\hline Dewhurst et al. 2003a (1) & White clover vs. grass & No effect & No effect \\
\hline Dewhurst et al. 2003a (2) & White clover vs. grass & Reduction & Increase \\
\hline Broderick et al. 2000 & Red clover vs. lucerne & Reduction & Small reduction \\
\hline Broderick et al. 2001 (1) & Red clover vs. lucerne & No effect & No effect \\
\hline Broderick et al. 2000 (2) & Red clover vs. lucerne & Reduction & No effect \\
\hline Hoffman et al. 1997 (1) & Red clover vs. lucerne & No effect & No effect \\
\hline Hoffman et al. 1997 (2) & Red clover vs. lucerne & No effect & Reduction \\
\hline Steinshamn \& Thuen (2008) & Red clover vs. white clover & Tendency for reduction & Small reduction \\
\hline
\end{tabular}

${ }^{\dagger}(1)$ and (2) refer to separate experiments reported within the same paper.

Dewhurst et al. (2010) and Cheng et al. (2011) found no differences in milk fat concentration and milk protein concentration when comparing diets based on grass silages and diets based on a series of mixtures of red clover silage with either maize silage or whole-crop oat silage. Phipps et al. (2000) found no consistent effect of maize silage maturity on milk fat concentration or protein concentration.

\section{Milk fatty acids}

In comparison with milk from cows fed grass silages, clover silages had only small and inconsistent effects on proportions of the various saturated fatty acids, as well as conjugated linoleic acid, in milk (Dewhurst et al. 2006). In contrast, both red clover and white clover silages led to highly significant increases in the proportion of the $n-3$ fatty acid $\alpha$-linolenic acid (18:3 $n-3)$ in milk. Figure 1 summarises the results of a number of comparisons of effects of grass silage and red clover silage on proportions of 18:3n-3 in milk fat. There was a three-fold increase in this fatty acid when red clover silage made up a high proportion of the diet (concentrate level was $4 \mathrm{~kg} / \mathrm{day}$ ) in 
the studies reported by Dewhurst et al. (2003b) and Moorby et al. (2009). Other studies have confirmed the increase in 18:3 content of milk from cows fed red clover silage (Al-Mabruk et al. 2004, Vanhatalo et al. 2007, Van Dorland et al. 2008) and white clover silage (Van Dorland et al. 2008). Vanhatalo et al. (2007) showed a greater increase in 18:3 content of milk fat for early-cut red clover silage in comparison with late-cut red clover silage. Dewhurst et al. (2003b) observed intermediate levels of 18:3 in milk when feeding mixtures of grass silage and red clover silage; Arvidsson et al. (2012) found only small but statistically significant increases when feeding a mixture of timothy and red clover silage.

The effect of clover silages is probably the basis for increased levels of 18:3 in organic milk, at least in the UK where red and white clover are important components of organic systems (Dewhurst, 2003, Ellis et al. 2006, Butler et al. 2011; Figure 2). Steinshamn and Thuen (2008) compared diets based on grass silage with either white clover silage ( 0.28 of DM) or red clover silage ( 0.42 of DM), either as sole-feed or with $10 \mathrm{~kg} \mathrm{day}^{-1}$ concentrates,

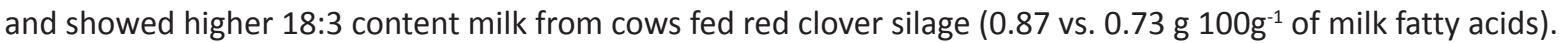

The mechanism for these effects relates to a reduction in rumen biohydrogenation of 18:3 from red clover silage and white clover silage. They cannot be explained as a dilution effect since yields of milk fat from cows fed clover silages were increased in comparison with yields from grass silage (Dewhurst et al. 2003a). In the case of red and white clover silages, this may be related to the higher rate of passage from the rumen (Dewhurst et al. 2003a), whilst in the case of red clover silage, it appears also related to the action of PPO (Lee et al. 2008).
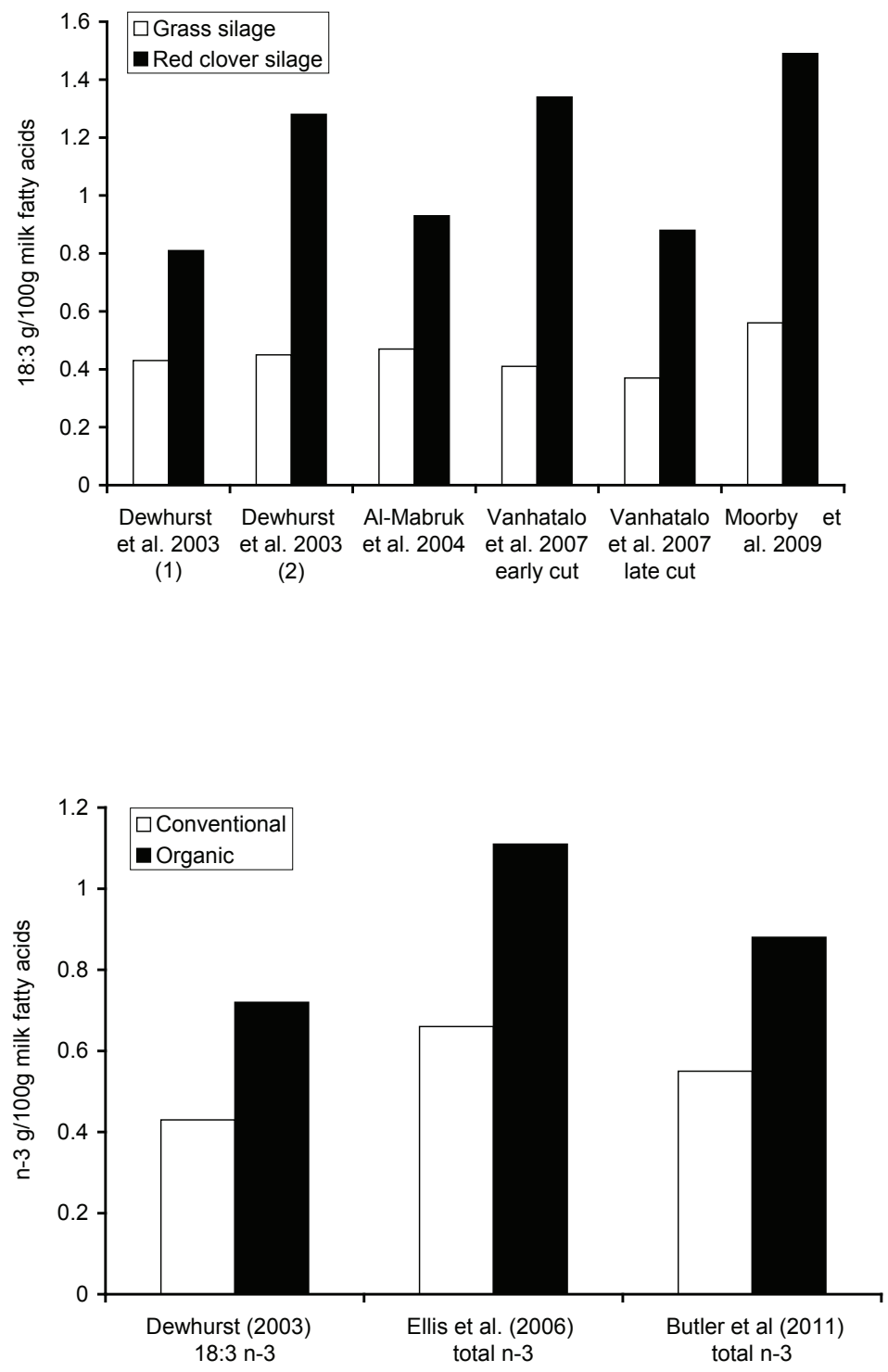

Fig. 1 Effect of replacing grass silage with red clover in the diet of lactating dairy cows on the proportion of 18:3 n-3 fatty

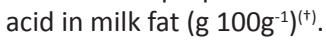

${ }^{\dagger}(1)$ and (2) refer to separate experiments reported within the same paper.
Fig. 2 Comparisons of proportions of $n-3$ polyunsaturated fatty acids in milk from cows fed conventional or organic diets based on surveys of farms or retail milk conducted in the UK. 


\section{Other milk attributes}

The increase in polyunsaturated fatty acids, both 18:2 and 18:3, in milk from cows fed red clover silage increases the likelihood of problems with oxidation. Al-Mabruk et al. (2004) demonstrated a reduction in the shelf-life of milk from cows fed diets based on red clover silage.

Bertilsson and Murphy (2003) observed an increased deviation from good organoleptic characteristics of milk when grass silage was replaced with silage made from white, and particularly, red clover silage. It seems likely that higher levels of dietary protein are one cause of off-flavours since compounds such as methyl sulphide and skatole are derived from degradation of amino acids. Ethanol is another silage component that can lead to offflavour in milk (Randby et al. 1999).

Moorby et al. (2009) showed changes in the physical appearance of milk produced from red clover silage in comparison with grass silage. Milk from cows fed red clover silage had a reduced whiteness score and a 'thinner' texture; it was suggested that this relates to lower levels of $\beta$-carotene in the milk. Feeding cows diets based on red clover silage increased levels of flavonoids (Steinshamn et al. 2008), which may affect human health.

\section{Utilisation of dietary $\mathrm{N}$ and urinary $\mathrm{N}$ output}

Kebreab et al. (2001) analysed a series of five N Balance studies conducted at the Centre for Dairy Research in Reading, with 30 diets based on grass silage and concentrates and obtained the following relationship (equation 1) for urine $N$ output:

Urine $\mathrm{N}\left(\mathrm{g} \mathrm{day}^{-1}\right)=0.003 \mathrm{~N}$ intake $\left(\mathrm{g} \mathrm{day}^{-1}\right)^{1.8}\left(\mathrm{r}^{2}=0.67\right.$ based on individual values $)$

Huhtanen et al. (2008) obtained a relationship (equation 2) that produces very similar predictions within the range of $\mathrm{N}$ intake encountered in practice. This relationship was based on a large number of treatment means taken from the literature and was based largely on grass silage-based diets:

Urine $\mathrm{N}(\mathrm{g} /$ day $)=-126+0.676 \mathrm{~N}$ intake $\left(\mathrm{g} \mathrm{day}^{-1}\right) \quad(\mathrm{n}=515, \mathrm{RMSE}=12.3)$

As might be predicted from equations (1) and (2), the high $\mathrm{N}$ content of legume silages can lead to low efficiencies of conversion into milk N (NUE) and particularly high urinary N output (Cohen et al. 2006, Dewhurst et al. 2003b, 2009). Urine $N$ has been reduced by offering low protein supplements, such as barley (Cohen et al. 2006) or maize silage (Margan et al. 1994, Auldist et al. 1999, Dewhurst et al. 2010) alongside legume silages. There is no evidence that the inefficiency is driven by asynchronous supply of energy and $\mathrm{N}$ to rumen micro-organisms since meal patterns had no effect on NUE (Cohen et al. 2006).

Whilst the high urine $\mathrm{N}$ from diets based on legume silages as sole forage are as expected, it is important not to miss two attributes of legume silages that may improve NUE and reduce urine $\mathrm{N}$ relative to expectations. The first mechanism relates to the action of the enzyme polyphenol oxidase (PPO) in red clover. PPO produces quinones that bind to proteins and reduce N degradability in the rumen (Broderick and Albrecht 1997, Cassida et al. 2000). Red clover silage contains approximately 0.3 to 0.4 (proportionately) less non-protein- $\mathrm{N}$ than lucerne silage (Albrecht and Muck 1991, Owens et al. 1999). This may explain observations of reduced rumen ammonia, reduced milk urea $\mathrm{N}$, reduced urine $\mathrm{N}$, and increased NUE with diets based on red clover silage in comparison with those based on lucerne silage (Broderick et al. 2000, 2001, 2007). We have used mixtures of red clover silage and maize silage to achieve the production benefits of legume silages, including increased milk protein yield, whilst reducing urine $\mathrm{N}$ production (Fig. 3 ). 


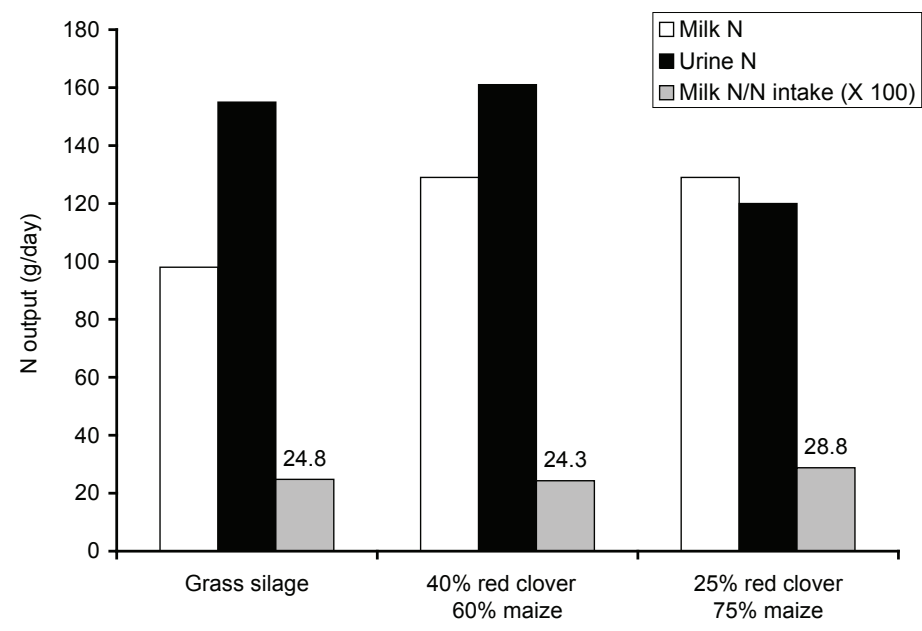

Fig. 3 Effect of replacing grass silage with mixtures of red clover silage and maize silage on outputs of milk $\mathrm{N}$ and urine $\mathrm{N}\left(\mathrm{g} \mathrm{day}^{-1}\right)$. Based on results of Dewhurst et al. 2010.

In two studies comparing grass silage-based diets with diets based on mixtures of legume silages and maize silage or other cereal silages, we noticed that urine $\mathrm{N}$ was 50 to $100 \mathrm{~g}_{\text {day }}{ }^{-1}$ less than predicted using equations (1) or (2) (Dewhurst et al. 2010, Cheng et al. 2011). Further analysis revealed that this effect was related to effects on DM intake. Further statistical analysis was conducted using treatment means from our studies (21 treatment means from Dewhurst et al. 2010, Cheng et al. 2011 and two unpublished studies with diets based on legume silages, grass silages and mixtures with maize silage). There was no significant relationship between DM intake and $\mathrm{N}$ intake for these treatment means $\left(r^{2}=0.07 ; p>0.1\right)$, so in addition to a simple regression (equation 3 ), we were able to conduct a multiple regression analysis (equation 4 ).

Urine $\mathrm{N}\left(\mathrm{g} \mathrm{day}^{-1}\right)=-122+0.614 \mathrm{~N}$ intake $\left(\mathrm{g} \mathrm{day}^{-1}\right)\left(\mathrm{r}^{2}=0.60, p<0.001\right)$

Urine $\mathrm{N}\left(\mathrm{g} \mathrm{day}^{-1}\right)=105.5+0.769 \mathrm{~N}$ intake $\left(\mathrm{g} \mathrm{day}^{-1}\right)-16.86 \mathrm{DM}$ intake $\left(\mathrm{kg} \mathrm{day}^{-1}\right)$

$\left(r^{2}=0.91, p<0.001\right)$

The interpretation of equation 4 is that diets affect urine $\mathrm{N}$ both through the supply of $\mathrm{N}$, and through effects on DM intake - presumably affecting the ability of the animal to utilise feed $\mathrm{N}$ in the rumen or tissues. In fact, the same effect was noted in the analysis by Huhtanen et al. (2008, equation 5), so there is a general principle that achieving higher intakes without increasing $\mathrm{N}$ intakes will increase NUE and reduce urine $\mathrm{N}$.

Urine $\mathrm{N}\left(\mathrm{g} \mathrm{day}^{-1}\right)=27+0.844 \mathrm{~N}$ intake $\left(\mathrm{g} \mathrm{day}^{-1}\right)-13.0 \mathrm{DM}$ intake $\left(\mathrm{kg} \mathrm{day}^{-1}\right)$

$(n=515, \operatorname{RMSE}=9.28)$

The effect described in equations (4) and (5) is the basis for the success of diets based on mixtures of legume and cereal silages. However, there are examples of this effect operating with other forages. Cushnahan et al. (1995) demonstrated a significantly higher proportion of $\mathrm{N}$ intake going to urine $\mathrm{N}$ with extensively-fermented grass silage of low intake characteristics, despite its having a lower N concentration. Cammell et al. (2000), comparing diets based on maize silages of varying digestibility, showed a reduction in urine $\mathrm{N}$, relative to $\mathrm{N}$ intake, with diets based on the maize silage ( $330 \mathrm{gDM} \mathrm{kg}^{-1}$ ) that maximised intake of digested organic matter, and thus, ME.

\section{Future research}

The effects of legume and maize silages in increasing feed intake and milk production are well-recognised, as are the effects of legume silages on milk fatty acids. It is likely that the use of legumes for silage will increase and there is a need to follow up on the increasing evidence of effects on the physical and organoleptic properties of milk. We need to properly describe the range and frequency of effects, as well as identifying the mechanisms involved, as a basis for amelioration strategies. 
Many of the benefits of legume silages in comparison with grass silages - increased intakes and milk production, increased polyunsaturated fatty acids in milk, and a reduction in urine $\mathrm{N}$ at a given $\mathrm{N}$ intake - relate to the increased rumen passage rates. In addition to seeking to change the chemical composition of grasses and silages, further work should investigate potential to achieve differences in physical and chemical breakdown characteristics of grasses (e.g. cell structure and lignification).

Whilst differences in rumen fermentation rate, particle breakdown, and passage from the rumen explain some of the higher intake with legume silages, there are clearly other facets of the control of silage intake that remain to be understood. Ammonia-N has long been recognized as merely a proxy for some aspects of poor fermentation quality in silages, which are not fully characterized. Ammonia and amines directly added to the diet have not reduced silage intake. Further studies are required to understand the complex balance between fermentation quality, effects on rumen kinetics and fill, as well as the balance between nutrient supply and animal requirements, in their effects on silage intake.

The observation that diets based on high intake characteristic forages leads to an increased NUE and a reduction in urine $\mathrm{N}$ should be investigated further. In particular, there is a need to understand the basis for the independent effects of $\mathrm{N}$ intake and $\mathrm{DM}$ intake since this offers potential to increase productivity without increasing problems linked to urine $\mathrm{N}$ output. Many aspects of good grassland management result in high levels of herbage $\mathrm{N}$, and the search for low N/high intake forages may be limited by the requirement to have protein present in the plant photosynthetic machinery. Differences in rumen microbial efficiency appear to explain only a small proportion of the effect, which appears to be more based at the tissue level.

The lack of data on methane production from alternative silages is an important gap to fill, particularly in the case of legume silages that have the additional benefit of reducing carbon intensity of production by replacing inorganic $\mathrm{N}$ fertilizer.

\section{References}

Abrahamse, P.A., Vlaeminck, B., Tamminga, B. \& Dijkstra, J. 2008. The effect of silage and concentrate type on intake behaviour, rumen function, and milk production in dairy cows in early and late lactation. Journal of Dairy Science 91: 4778-4792.

Albrecht, K.A. \& Muck, R.E. 1991. Proteolysis in ensiled forage legumes that vary in tannin concentration. Crop Science 31: 464-469. Allen, M.S. 2000. Effects of diet on short-term regulation of feed intake by lactating dairy cattle. Journal of Dairy Science 83: 1598-1624.

Al-Mabruk, R.M., Beck, N.F.G. \& Dewhurst, R.J. 2004. Effects of silage species and supplemental vitamin E on oxidative stability of milk. Journal of Dairy Science 87: 406-412.

Arvidsson, K., Gustavsson, A.-M., Fievez, V. \& Martinsson, K. 2012. The effect of N-fertilisation rate or inclusion of red clover to timothy leys on fatty acid composition in milk of dairy cows fed a commercial silage: concentrate ratio. Animal 6: $1178-1186$.

Auldist, D.E., Atkinson, K.L., Silvapulle, M.J., Dellow, D.W. \& McDowell, G.H. 1999. Utilisation of white clover silage fed alone or with maize silage by lactating dairy cows. Australian Journal of Experimental Agriculture 39: 237-246.

Baumont, R. \& Deswysen, A.G. 1991. [Mixing and propulsion of the contents of the reticulo-rumen]. Reproduction, Nutrition et Development 31: 335-359.

Beauchemin, K.A., Kreuzer, M., O’Mara, F. \& McAllister, T. A. 2008. Nutritional management for enteric methane abatement: A review. Australian Journal of Experimental Agriculture 48: 21-27.

Beever, D.E., Dhanoa, M.S., Losada, H.R., Evans, R.T., Cammell, S.B. and France J. 1986. The effect of forage species and stage of harvest on the process of digestion occurring in the rumen of cattle. British Journal of Nutrition 56: 439-454.

Beever, D.E. \& Thorp, C. 1996. Advances in the understanding of factors influencing the nutritive value of legumes. In: Younie, D. (ed.). Legumes in Sustainable Farming Systems. British Grassland Society Occasional Symposium No. 30. p. $194-207$.

Bertilsson, J. \& Murphy, M. 2003. Effects of feeding clover silages on feed intake, milk production and digestion in dairy cows. Grass and Forage Science 58: 309-322.

Bhandari, S.K., Li, S., Ominski, K.H., Wittenberg, K.M. \& Plazier, J.C. 2008. Effects of chop length of alfalfa silage and oat silage on feed intake, milk production, feeding behaviour, and rumen fermentation of dairy cows. Journal of Dairy Science 91: $1942-1958$.

Bhandari, S.K., Ominski, K.H., Wittenberg, K.M. \& Plazier, J.C. 2007.Effects of chop length of alfalfa and corn silage on milk production and rumen fermentation of dairy cows. Journal of Dairy Science 90: 2355-2366.

Blaxter, K.L. \& Clapperton, J.L. 1965. Prediction of the amount of methane produced by ruminants. British Journal of Nutrition 19: $511-522$.

Bosch, M.W. \& Bruining, M. 1995. Passage rate and total clearance rate from the rumen of cows fed on grass silage differing in cell-wall content. British Journal of Nutrition 73: 41-49.

Broderick, G.A. \& Albrecht, K.A. 1997. Ruminal in vitro degradation of protein in tannin-free and tannin-containing forage legume species. Crop Science 37: 1884-1891. 
Broderick, G.A., Albrecht, K.A., Owens, V.N. \& Smith, R.R. 2004. Genetic variation in red clover for rumen protein degradability. Animal Feed Science and Technology 113: 157-167.

Broderick, G.A., Brito, A.F. \& Olmos Colmenero, J.J. 2007. Effects of feeding formate-treated alfalfa silage or red clover silage on the production of lactating dairy cows. Journal of Dairy Science 90: 1378-1391.

Broderick, G.A., Walgenbach, R.P. \& Maignan, S. 2001. Production of lactating dairy cows fed alfalfa or red clover silage at equal dry matter or crude protein contents in the diet. Journal of Dairy Science 84: 1728-1737.

Broderick, G. A., Walgenbach, R.P. \& Sterrenburg, E. 2000. Performance of lactating dairy cows fed alfalfa or red clover silage as the sole forage. Journal of Dairy Science 83:1543-1551.

Butler, G., Stergiadis, S., Seal, C., Eyre, M. \& Leifert, C. 2011. Fat composition of organic and conventional retail in northeast England. Journal of Dairy Science 94: 24-36.

Cammell, S.B. Sutton, J.D., Beever, D.E., Humphries, D.J. \& Phipps, R.H. 2000. The effect of crop maturity on the nutritional value of maize silage for lactating dairy cows. 1. Energy and nitrogen utilization. Animal Science 71: 381-390.

Cassida, K.A., Griffin, T.S., Rodriguez, J., Patching, S.C., Hesterman, O.B. \& Rust, S.R. 2000. Protein degradability and forage quality in maturing alfalfa, red clover and birdsfoot trefoil. Crop Science 40: 209-215.

Castle, M.E. 1982. Feeding high-quality silage. In: Rook J.A.F. \& Thomas, P.C. (eds.). Silage for Milk Production. National Institute for Research in Dairying/Hannah Research Institute Technical Bulletin 2. p. 127-150.

Castle, M.E., Reid, D. \& Watson, J.N. 1983. Silage and milk production: studies with diets containing white clover silage. Grass and Forage Science 38: 193-200.

Castle, M.E., Reid, D. \& Watson, J.N. 1984. Silage and milk production: a comparison between supplements of barley and soybean meal offered with white clover silage. Grass and Forage Science 39: 287-289.

Cheng, L., Kim, E.J., Merry, R.J. \& Dewhurst, R.J. 2011. Nitrogen partitioning and isotopic fractionation in dairy cows consuming diets based on a range of contrasting forages. Journal of Dairy Science 94: 2031-2041.

Cohen, D.C., Stockdale, C.R. \& Doyle, P.T. 2006. Feeding an energy supplement with white clover silage improves rumen fermentation, metabolisable protein utilisation, and milk production in dairy cows. Australian Journal of Agricultural Research 57: 367-375.

Cushnahan, A., Mayne, C.S. \& Unsworth, E.F. 1995. Effects of ensilage of grass on performance and nutrient utilization by dairy cattle. 2. Nutrient metabolism and rumen fermentation. Animal Science 60: 347-359.

Dewhurst, R.J. 2003. Fatty acids in milk fat from organic dairy farms. Elm Farm Research Centre Bulletin, October, 11. Organic Research Centre, Elm Farm, Newbury, UK.

Dewhurst, R.J., Davies, L.J. \& Kim, E.J. 2010. Effects of mixtures of red clover and maize silages on the partitioning of dietary nitrogen between milk and urine by dairy cows. Animal 4: 732-738.

Dewhurst, R.J., Delaby, L., Moloney, A., Boland, T. \& Lewis, E. 2009. Nutritive value of forage legumes used for grazing and silage. Irish Journal of Agricultural and Food Research 48: 167-187.

Dewhurst, R.J., Evans, R.T., Scollan, N.D., Moorby, J.M., Merry, R.J. \& Wilkins, R.J. 2003a. Comparison of grass and legume silages for milk production. 2. In vivo and in sacco evaluations of rumen function. Journal of Dairy Science 86: 2612-2621.

Dewhurst, R.J., Fisher, W.J., Tweed, J.K.S. \& Wilkins, R.J. 2003b. Comparison of grass and legume silages for milk production. 1. Production responses with different levels of concentrate. Journal of Dairy Science 86: 2598-2611.

Dewhurst, R.J., Shingfield, K.J., Lee, M.R.F. \& Scollan, N.D. 2006. Increasing the concentrations of beneficial polyunsaturated fatty acids in milk produced by dairy cows in high-forage systems. Animal Feed Science and Technology 131: 168-206.

Ellis, K.A., Innocent, G., Grove-White, D., Cripps, P., McLean, W.G., Howard, C.V. \& Mihm, M. 2006. Comparing the fatty acid composition of organic and conventional milk. Journal of Dairy Science 89: 1938-1950.

Hetta, M., Gustavsson, A-M., Cone, J.W. \& Martinsson, K. 2004. In vitro degradation characteristics of timothy and red clover at different times. Acta Agriculturae Scandinavica, Section A - Animal Sciences 54: 20-29.

Hoffman, P.C., Combs, D.K., Brehm, N.M. \& Welch, D.A. 1997. Performance of lactating dairy cows fed red clover or alfalfa silage. Journal of Dairy Science 80: 3308-3315.

Hoffman, P.C., Combs, D.K. \& Casler, M.D. 1998. Performance of lactating dairy cows fed alfalfa silage or perennial ryegrass silage. Journal of Dairy Science 81: 162-168.

Hoffman, P.C., Sievert, S.J., Shaver, R.D., Welch, D.A. \& Combs, D.K. 1993. In situ dry matter, protein, and fiber degradation of perennial forages. Journal of Dairy Science 76: 2632-2643.

Huhtanen P., Nousiainen, J.I., Rinne, M., Kytölä, K. \& Khalili, H. 2008. Utilisation and partition of dietary nitrogen in dairy cows fed grass silage-based diets. Journal of Dairy Science 91: 3589-3599.

Huhtanen, P., Rinne, M. \& Nousiainen, J. 2007. Evaluation of the factors affecting silage intake of dairy cows: a revision of the relative silage dry-matter intake index. Animal 1: 758-770.

INRA, 2007. Alimentation des bovins, ovins et caprins. Quae Eds, Versailles, France, $330 \mathrm{p}$.

Jamot, J. \& Grenet, E. 1991. Microscopic investigation of changes in histology and digestibility in the rumen of a forage grass and forage legume during the first growth stage. Reproduction, Nutrition, Développement 31: 441-450.

Kebreab, E., France, J., Beever, D.E. \& Castillo, A.R. 2001. Nitrogen pollution by dairy cows and its mitigation by dietary manipulation. Nutrient Cycling in Agroecosystems 60: 275-285.

Kingston-Smith, A.H., Marshall, A.H. \& Moorby, J.M. 2013. Breeding for genetic improvement of forage plants in relation to increasing animal production with reduced environmental footprint. Animal doi:10.1017/S17517311120000961. 
Kuoppala, K., Ahvenjärvi, S., Rinne, M. \& Vanhatalo, A. 2009. Effects of feeding grass or red clover silage cut at two maturity stages in dairy cows. 2. Dry matter intake and cell wall digestion kinetics. Journal of Dairy Science 92: 5634-5644.

Kuoppala, K., Rinne, M. Ahvenjärvi, S., Nousiainen, J. \& Huhtanen, P. 2010. The effect of harvesting strategy of grass silage on digestion and nutrient supply in dairy cows. Journal of Dairy Science 93: 3253-3263.

Lee, M.R.F., Olmos Colmenero, J.D.J., Winters, A.L., Scollan, N.D. \& Minchin, F.R. 2006. Polyphenol oxidase activity in grass and its effect on plant-mediated lipolysis and proteolysis of Dactylis glomerata (cocksfoot) in a simulated rumen environment. Journal of the Science of Food and Agriculture 86: 1503-1511.

Lee, M.R.F., Scott, M.B., Tweed, J.K.S., Minchin, F.R. \& Davies, D.R. 2008. Effects of polyphenol oxidase on lipolysis and proteolysis of red clover silage with and without a silage inoculant (Lactobacillus plantarum L54). Animal Feed Science and Technology 144: 125-136.

Margan, D.E., Moran, J.B. \& Spence, F.B. 1994. Energy and protein value of combinations of maize silage and red clover hay for ruminants, using adult sheep as a model. Australian Journal of Experimental Agriculture 34: 319-329.

McCartney, C.A., Bull, I.D. \& Dewhurst, R.J. 2012. Archaeol concentration in total rumen contents of cows offered diets based on ryegrass or white clover. Page 99 in: Proceedings of the Irish Agricultural Research Forum, $12^{\text {th }}$ and $13^{\text {th }}$ March, 2012, Tullamore, Ireland.

McCaughey, W.P., Wittenberg, K. \& Corrigan, D. 1999. Impact of pasture type on methane production by lactating beef cows. Canadian Journal Animal Science 79: 221-226.

Moorby, J.M., Lee, M.R.F., Davies, D.R., Kim, E.J., Nute, G.R., Ellis, N.M. \& Scollan, N.D. 2009. Assessment of dietary ratios of red clover and grass silages on milk production and milk quality in dairy cows. Journal of Dairy Science 92: 1148-1160.

Moseley, G. \& Jones, J.R. 1984. The physical digestion of perennial ryegrass (Lolium perenne) and white clover (Trifolium repens) in the foregut of sheep. British Journal of Nutrition 52: 381-390.

Owens, V.N., Albrecht, K.A. \& Muck, R.E. 1999. Protein degradation and ensiling characteristics of red clover and alfalfa wilted under varying levels of shade. Canadian Journal of Plant Science 79: 209-222.

Phipps, R.H., 1990. Maize: a review of research findings in relation to animal production. In: Milk and Meat from Forage Crops. G. E Pollott (ed.). British Grassland Society Occasional Publication Number 24. p.107-119.

Phipps, R.H., Sutton, J.D., Beever, D.E. \& Jones, A.K. 2000. The effect of crop maturity on the nutritional value of maize silage for lactating dairy cows 3. Food intake and milk production. Animal Science 71: 401-409.

Phipps, R.H., Weller, R.F., Elliot, R.J., \& Sutton, J.D. 1988. The effect of level and type of concentrate and type of conserved forage on dry matter intake and milk production of lactating dairy cows. Journal of Agricultural Science (Cambridge) 111: 179-186.

Phipps, R.H., Weller, R.F. \& Rook, A.J. 1992. Forage mixtures for dairy cows: the effect on dry matter intake and milk production of incorporating different proportions of maize silage into diets based on grass silage of differing energy value. Journal of Agricultural Science (Cambridge) 118: 379-382.

Rae, R.C., Thomas, C., Reeve, A., Golightly, A.J., Hodson, R.G. \& Baker, R.D. 1987. The potential of an all-grass diet for the latewinter calving dairy cow. Grass and Forage Science 42: 249-257.

Randby, Å.T., Selmer-Olsem, I. \& Baevre, L. 1999. Effect of Ethanol in Feed on Milk Flavor and Chemical Composition. Journal of Dairy Science 82: 420-428.

Rinne, M., Huhtanen, P. \& Jaakkola, S. 2002. Digestive processes of dairy cows fed silages harvested at four stages of grass maturity. Journal of Dairy Science 80: 1986-1998.

Rinne, M. \& Nykänen, A. 2000. Timing of primary growth harvest affects the yield and nutritive value of timothy-red clover mixtures. Agricultural and Food Science in Finland 9: 121-134.

Rustas, B.-O., Nørgaard, P., Jalali, A.R. \& Nadeau, E. 2010. Effects of physical form and stage of maturity at harvest of whole-crop barley silage on intake, chewing activity, diet selection and faecal particle size of dairy steers. Animal 4: 67-75.

Smith, L.W., Goering, H.K. \& Gordon, C.H. 1972. Relationships of forage compositions with rates of cell wall digestion and cell wall indigestibility. Journal of Dairy Science 55: 1140-1147.

Steinshamn, H., Purup, S., Thuen, E. \& Hansen-Møller, J. 2008. Effects of clover-grass silages and concentrate supplementation on the content of phytoestrogens in dairy cow milk. Journal of Dairy Science 91: 2715-2725.

Steinshamn, H. \& Thuen, E. 2008. White or red clover-grass silage in organic dairy milk production: Grassland productivity and milk production responses with different levels of concentrate. Livestock Science 119: 202-215.

Theodoridou, K., Aufrère, J., Andueza, D., Le Morvan, A., Picard, F., Porrat, J. \& Baumont, R. 2012. Effects of condensed tannins in wrapped silage bales of sainfoin (Onobrychis viciifolia) on in vivo and in situ digestion in sheep. Animal 6: 245-253.

Thomas, C., Aston, K. \& Daley, S.R. 1985. Milk production from silage. 3. A comparison of red clover with grass silage. Animal Production 41: 23-31.

Thomas, C., Gibbs, B.G. \& Tayler, J.C. 1981. Beef production for silage. 2. The performance of beef cattle given silages of either perennial ryegrass or red clover. Animal Production 32: 149-153.

Ulyatt, M.J. 1970. Evaluation of pasture quality under New Zealand conditions. Proceedings of the New Zealand Grassland Association 32: 61-68.

Van Dorland, H.A., Kreuzer, M., Leuenberger, H. \& Wettstein, H.-R. 2008. Comparative potential of white and red clover to modify the milk fatty acid profile of cows fed ryegrass-based diets from zero-grazing and silage systems. Journal of the Science of Food and Agriculture 88: 77-85.

Van Dorland, H.A., Wettstein, H.-R., Leuenberger, H. \& Kreuzer, M. 2007. Effect of supplementation of fresh and ensiled clovers to ryegrass on nitrogen loss and methane emissions in dairy cows. Livestock Science 111: 57-69. 
Vanhatalo, A., Kuoppala, K., Ahvenjärvi, S. \& Rinne, M. 2009. Effects of feeding grass or red clover silage cut at two maturity stages in dairy cows. 1. Nitrogen metabolism and supply of amino acids. Journal of Dairy Science 92: 5620-5633.

Vanhatalo, A.S., Kuoppala. K., Toivonen, V. \& Shingfield, K.J. 2007. Effects of forage species and stage of maturity on bovine milk fatty acid composition. European Journal of Lipid Science and Technology 109: 856-867.

Vanhatalo, A., Pursiainen, P., Kuoppala, K., Rinne, M. \& Tuori, M. 2008. Effects of harvest time of red clover silage on milk production and composition. Grassland Science in Europe 13: 391-393.

Vellinga, T.V. \& Hoving, I.E. 2011. Maize silage for dairy cows: mitigation of methane emissions can be offset by land use change. Nutrient Cycling in Agroecosystems 89: 413-426.

Waghorn, G.C., Shelton, I.D. \& Thomas, V.J. 1989. Particle breakdown and rumen digestion of fresh ryegrass (Lolium perenne L.) and lucerne (Medicago sativa L.) fed to cows during a restricted feeding period. British Journal of Nutrition 61: 409-423.

Waghorn, G.C., Woodward, S.L., Tavendale, M. \& Clark, D.A. 2006. Inconsistencies in rumen methane production - effects of forage composition and animal genotype. International Congress Series 1293: 115-118.

Wilman, D., Mtengeti, E.J. \& Moseley, G. 1996. Physical structure of twelve forage species in relation to intake by sheep. Journal of Agricultural Science (Cambridge) 126: 277-285.

Wilson, J.R. \& Kennedy, P.M. 1996. Plant and animal constraints to voluntary feed intake associated with fibre characteristics and particle breakdown and passage in ruminants. Australian Journal of Agricultural Research 47: 199-225. 